\title{
The State-of-the-Art Estimation of Groundwater Recharge and Water Balance with a Special Emphasis on India: A Critical Review
}

\author{
Pazhuparambil Jayarajan Sajil Kumar ${ }^{1, *}$, Michael Schneider ${ }^{1}$ and Lakshmanan Elango ${ }^{2}$ \\ 1 Hydrogeology Group, Institute of Geological Sciences, Freie Universität Berlin, 12249 Berlin, Germany; \\ m.schneider@fu-berlin.de \\ 2 Department of Geology, Anna University, Chennai 600025, India; elango@annauniv.edu \\ * Correspondence: pjsajil@gmail.com
}

\section{check for}

updates

Citation: Sajil Kumar, P.J.;

Schneider, M.; Elango, L. The

State-of-the-Art Estimation of Groundwater Recharge and Water Balance with a Special Emphasis on India: A Critical Review.

Sustainability 2022, 14, 340. https:// doi.org/10.3390/su14010340

Academic Editors: Hwa-Lung Yu, Shao-Yiu Hsu, Jui-Pin Tsai and Yojin Shiau

Received: 14 November 2021 Accepted: 18 December 2021 Published: 29 December 2021

Publisher's Note: MDPI stays neutral with regard to jurisdictional claims in published maps and institutional affiliations.

Copyright: () 2021 by the authors Licensee MDPI, Basel, Switzerland. This article is an open access article distributed under the terms and conditions of the Creative Commons Attribution (CC BY) license (https:// creativecommons.org/licenses/by/ $4.0 /)$.

\begin{abstract}
Groundwater recharge estimation is essential for sustainable water management and water supply schemes. In this paper, we review groundwater recharge estimation techniques and identify the appropriate methods by considering India's hydrological and climatic conditions. Significant components of recharge, factors affecting groundwater recharge, aquifer systems of India, and historical groundwater recharge estimation practices are reviewed. Currently used recharge estimation methods are assessed based on case studies. The most popular estimation methods are studied and compared based on their application in various regions. It is observed that the accuracy of the recharge estimates is largely influenced by false assumptions, the possibility of erroneous measurements, a potential lack of reliable data, and a variety of problems associated with parameter estimation. The suitability of different methods for a region is found to depend on time and space considerations, the objective of the study, hydrogeological condition, and availability of data. In Indian conditions, it is suggested to use water table fluctuation and water balance methods for the recharge estimation, provided that accurate water level measurements are assured.
\end{abstract}

Keywords: groundwater; aquifers; recharge estimation; suitability analysis

\section{Introduction}

Increasing urbanization, industrialization, and population growth continuously increase the demand for water on a global scale. It is reported that around one-third of the world's population experiences water shortages at least one month per year [1]. The United Nations General assembly has shown concern over the human right to water and sanitation on several occasions [2,3]. Surface water was the most accessible source for domestic and agricultural purposes for many generations. Preference has been given to groundwater in recent years, mainly because of the pollution, river depletion, and scarcity of surface water due to failure in precipitation. Groundwater is readily available in nature, and its occurrence within the premises of stakeholders has made it preferable over surface waters. In India, on a national level, groundwater serves $50-80 \%$ of domestic and $45-50 \%$ of all irrigation needs $[4,5]$.

India has faced high water shortages for the past few decades due to increased population, industrialization, climate change, and unsustainable management of water resources. A considerable reduction in freshwater availability was reported from $5177 \mathrm{~m}^{3}$ in 1951 to $1820 \mathrm{~m}^{3}$ in 2001, further reducing to $1545 \mathrm{~m}^{3}$ in 2011 (Ministry of Water Resources). A central groundwater authority was founded in 1986 to suggest preparatory measures for regulating uncontrolled exploitation of groundwater [6].

Important factors in controlling the sustainability and stability of any system are an equilibrium between inflow and outflow. In the case of groundwater, this generally comprises three factors: inflow, outflow and change in the storage of groundwater. Water 
balance is an important factor determining groundwater systems' efficiency and recurrence [7]. The replenishment of groundwater in nature is maintained by recharging [8]. The downward movement of water from various sources to the subsurface and ultimately reaching the water table is called groundwater recharge.

Groundwater recharge is variable because of natural factors such as climate, land cover, geology, morphology, rainfall timing and intensity, soil type, and vegetation [9-11]. Additionally, artificial topography modification, land use, land cover, etc., also affect recharge. The major sources of recharge are infiltration of rainfall, recharge along watercourses, lakes, irrigation return flow, and seepage through subsurface flow by natural hydraulic gradient $[12,13]$. The timely availability and distribution of source water play a vital role in the total groundwater recharge. In India, precipitation is the leading source of water for recharge. Thus, analyzing rainfall patterns, frequency, number of rainy days, and maximum rainfall in a day and its variation in space and time are the important factors influencing the recharge [14]. Surface water bodies such as rivers, lakes, canal seepage, surface, groundwater irrigation [15], and snow melting in the Himalayas also contribute to groundwater recharge [16]. Different lithology has different recharge characteristics. Sedimentary formations such as sand, gravels, fractures in hard rocks, fault zones, karst topography, and the absence of barriers such as impervious formations, etc., are of great importance. Recharge under different land use areas, i.e., forest, grassland, cropland, urban land with concrete pavements, etc., also varies considerably [17]. Climatic factors such as a change in precipitation, evapotranspiration, and a decrease in soil moisture with increasing temperature also affect the recharge rates [18]. In India, the spatial variation in rainfall distribution is extremely high and varies from 11,000 mm/year at Cheerapunji near Shillong to 200 $\mathrm{mm} /$ year in parts of Rajasthan $[19,20]$.

India is the largest user of groundwater in the world at $230 \mathrm{~km}^{3}$ [21]. The contribution of groundwater to drinking and irrigation purposes is $85 \%$ and $60 \%$, respectively. In India, $85-90 \%$ of the rural population and $48 \%$ of the urban population depend on groundwater for their drinking water supply [21-23]. According to the Ministry of Agriculture (2013), nearly $70 \%$ of irrigation was dependent on groundwater in 2013, which increased to $90 \%$ in 2018 [24,25]. India's government water supply and sanitation program covers only $74 \%$ of households, and those remaining have no access to these facilities. Considering this situation in India, there must be adequate water resources management, and it is essential to implement measures to increase groundwater recharge. Such efforts have been made by many researchers and by governmental agencies. The most important step was made in 1972 by India's Ministry of Agriculture by recommending guidelines for groundwater evaluation. The "Ground Water Estimation Committee" (GEC) proposed a definite scientific norm only in 1984. They recommended two methods: groundwater level fluctuation (WLF) and specific yield method, and the rainfall infiltration method for the groundwater resource assessment. The WLF method is suggested for the monsoon season, and rainfall infiltration factor norms can be used in case of a lack of data on the water level. The major advantages of these methods are that they are simple, with easy access to the data from the corresponding departments, as the WLF method is based on a widely-accepted principle of groundwater balance. If there are no reliable data available for WLF method, then the rainfall infiltration method is used. Several limitations exist, as it is recommended to use a block as a unit of measurement, and other than this, no specific unit is suggested. This unit is unable to represent the spatial variability of recharge within the groups and additionally, the baseflow is not accounted for in the norms. A few refinements can be made by considering these limitations, and improvements were suggested when the watershed is considered as an assessment unit with due consideration of the geomorphological and hydrogeological conditions. Seasonal assessment of the recharge and a different specific yield estimation are suggested for hard rock and alluvial areas.

Our aim with this paper is to review existing groundwater recharge estimation techniques globally and critically assess these methods in Indian conditions, and to choose 
appropriate recharge estimation techniques based on hydrological, hydrogeological, climatic, and time and space constraints.

\section{Review of Commonly Used Groundwater Recharge Estimation Techniques}

Groundwater recharge estimation techniques can be generally classified into physical methods, chemical methods, and numerical methods. All these models are theoretically significant but failed or proved to be incorrect because of problems with accuracy or difficulties in implementation.

\subsection{Physical Methods}

Physical methods are the most straightforward and most common measure of recharge by precipitation. These methods are popular because they give direct results, are easy to measure, and can be performed without much expense [25]. The influence of topography, soil characteristics, and climatic conditions are greater in these methods. Aquifer media of the region play an important role in determining the actual and potential recharge [26]. The most important physical methods used in the field are presented in the following sections.

\subsubsection{Zero Flux Plane (ZFP) Method}

A zero-flux plane (ZFP) is the plane that distinguishes the upward movement of water for evaporation and the downward movement to the water table and subsequent drainage to completely wetted deep soil $[27,28]$. This condition exists when evaporation surpasses rainfall. Simultaneous downward drainage and upward movement then occur. Tensiometers can be used to fix the region of zero hydraulic gradients. The volume for water passing through a unit area per unit time is the flux $(q)$, which Darcy's law can obtain:

$$
q=-K(\theta) \delta H / \delta z
$$

where $K(\theta)=$ unsaturated hydraulic conductivity, $H=$ total water potential $h(\theta)-z$, $h=$ matric potential (negative), $z=$ depth below the surface, and $\theta=$ water content.

Common problems face the determination of $K$, which may vary from place to place. The ZFP method is limited to regions where FP exists, and where the water table is deeper than the ZFP (USGS).

\subsubsection{Soil Water Balance Method}

The basic concept of the soil water balance method is calculating the balance between inflow and outflow, and the water required for soil to become saturated and is expressed as the depth of water. This method was initially developed by Thornthwaite [29] and modified by many researchers. This can be expressed as:

$$
R i=P \rightarrow E_{a}+\Delta W-R_{o}
$$

where $R i=$ recharge,$P=$ precipitation, $E_{a}=$ actual evapotranspiration, $\Delta W=$ change in soil water storage, and $R_{o}=$ runoff.

The change largely influences the practical significance of this method in soil water storage, which is never a direct measurement. In the case of large areas, different values must be given to all input parameters as per the ground conditions. As these parameters are measured in the field, a significant amount of uncertainty and inaccuracy is often encountered. Additionally, an extensive set of data is needed to perform these calculations.

\subsubsection{Groundwater Level Fluctuation Method}

The groundwater level fluctuation method is an indirect recharge measurement technique widely used for the recharge measurement of unconfined aquifers where groundwater fluctuation occurs seasonally. It is based on the concept that a rise in the water table is 
directly proportional to the amount of water that recharges to the groundwater table [25]. The general expression for recharge can be written as:

$$
R=S_{y} \frac{d h}{d t}=S_{y} \frac{\Delta h}{\Delta t}
$$

where $S y=$ specific yield,$h=$ hydraulic head, and $t=$ time.

This method assumes that subsurface inflow and outflow are uniformly distributed over the area. Therefore, this method's best suitable application sites are shallow water table regions with sharp rise and decline in water levels, especially within short time periods (hours or a few days [26,30]).

\subsubsection{Groundwater Balance Method}

Groundwater balance estimation remains one of the most straightforward methods used in understanding groundwater recharge. The water budget is one of the essential parts of any conceptual model [31]. The three essential components that must be accounted for in this method are inflow, outflow, and change in storage. A sufficient recharge estimate must also consider all the water that could not recharge the aquifer [31,32].

A general expression for the groundwater balance equation is as follows:

$$
\left(P+G_{\text {in }}\right)-\left(Q+E T+G_{\text {out }}\right)=\Delta S
$$

where $P=$ precipitation, $G_{i n}$ = groundwater inflow, $Q=$ discharge, $E T$ = evapotranspiration, $G_{\text {out }}=$ groundwater outflow, and $\Delta S=$ change is storage.

In the case of a typical unconfined aquifer, the major factors that contribute to the inflow and outflow components are recharged from rain, canals, irrigation, tanks, influent recharge from rivers, inflow from other basins, draft from groundwater, discharge to rivers, outflow to other basins, etc.

\subsection{Tracer Techniques}

Tracer techniques can estimate groundwater recharge without measuring water fluctuations. This method is now widely used in groundwater recharge estimation studies. Several researchers have made valuable contributions to the development of this method [19,33-37]. This method has been preferred over the other methods because the entire process is short term, and collecting the data is very easy. Tracers can be classified as historical, environmental, and applied tracers [38,39].

A historical tracer can be defined as a tracer with a very high concentration in the environment, resulting from mostly anthropogenic inputs such as nuclear testing and industrial or agricultural contaminant spills. Tracking the movement of this tracer will give important information on recharge. Some of the common tracers-bromide, nitrate, atrazine, and arsenic — are commonly derived from anthropogenic inputs [39].

Environmental traces are already available in nature by atmospheric deposition. Chloride is a critical tracer in this category. Estimation is based on mass balance studies based on its accumulation and spatial pattern. The application of this method can be found in both unconfined and confined aquifers.

Applied or artificial tracers are used in recharge estimation by enhancing their background concentration in nature. Some of the essential tracers in this category are chromium EDTA sodium iodide ammonium bromide, uranine sodium chloride, ammonium chloride, sodium iodide, etc. All the tracers assume that their movement will be directly proportional to the movement of water.

Among these, the most used tracer techniques are the chloride, tritium, and stable isotope methods. 


\subsubsection{Chloride Method}

Chloride is one of the best environmental tracers, satisfying most of the requirements of an ideal tracer, i.e., low cost and the conservative nature that allows for the preservation of atmospheric inputs. There is no such process in the subsurface that can alter the concentration by interacting with aquifer media or vegetation [40]. For a region, recharge can be estimated by the following method:

$$
R=P\left(C_{p}+C_{d}\right) / C_{s i}
$$

where $P=$ mean annual precipitation, $C p=$ weighted mean concentration of chloride in rainfall, $C d=$ the amount of chloride in the dry deposition, and $C s i=$ average concentration of chloride over interval $i$ in interstitial water in the unsaturated zone (as described in the literature [40-42]).

Though this method has many merits, there is a drawback in the ambiguity in accurately determining the chloride concentration in the wet and dry deposition. In addition, extreme rainfall events also may affect the concentration when calculating based on the mean annual rainfall.

\subsubsection{Tritium Method}

Tritium is used for the estimation of groundwater age and recharge rates. Atomic bomb tests in the 1960s were primarily responsible for concentrations of tritium in the atmosphere elevated above the normal level [43]. Production of tritium by the action of cosmic rays on the nitrogen atoms in the air helps maintain its current level [44]. Tritium is chosen as a tracer because of its shorter half-life than the other radioactive tracers. However, there are disadvantages such as the neoconservative nature of tritium, which results in the loss by evapotranspiration; thus, a mass balance study is not possible, contamination during the sample collection and processing is a problem, and the whole process is costly and needs exceptionally skilled people to conduct the studies.

\subsubsection{Stable Isotopes}

Oxygen-18 $\left({ }^{18} \mathrm{O}\right)$ and deuterium $\left({ }^{2} \mathrm{H}\right)$ are conservative isotopes that can be used for groundwater recharge estimation and give valuable inference to processes such as evaporation, transpiration, infiltration, etc. This method uses the differences in the isotopic concentrations in groundwater and precipitation by a mass balance approach $[45,46]$. Isotopic concentration in precipitation varies considerably from hilly to coastal regions, and from temperate to cold regions. One of the major disadvantages of the ${ }^{18} \mathrm{O} /{ }^{2} \mathrm{H}$ method is that it is costlier than the other fluorescent tracers, so application at small groundwater systems is not viable. Additionally, the analysis needs more sophisticated laboratory facilities, and it is a time-consuming process.

\subsection{Numerical Model-Based Estimation Methods}

Numerical model approaches establish a numerical relationship between the basic components in the water budget method and give the recharge estimate as a residual term [26]. In any modeling approach for groundwater, hydraulic conductivity is the decisive factor. Recharge rates for equal precipitation vary considerably under different hydraulic conductivities. Combining an unsaturated zone model with groundwater models can be effectively used to evaluate groundwater recharge $[47,48]$. Integrated models can predict the recharges with comparatively higher accuracy than simple groundwater models [49] (Sophocleus, 2002). Sanford [50] reported that knowledge of the process that controls the recharge rate is essential for a successful recharge model. The climate, geological framework, and topography are the three main factors that control water flow [50,51]. Based on aquifer characteristics, modeling methods are mainly classified as models based on the (i) unsaturated zone and (ii) saturated zone. Many studies describe unsaturated zone modeling very well $[26,52-55]$. In saturated zone modeling, the numerical groundwater 
models are often recommended to use inverse modeling [56,57]. The basic concept behind this technique is the correlation between groundwater recharge and hydraulic conductivity, and the reliability of the latter is the decisive factor of an accurate estimation $[26,47,58]$.

\subsubsection{One-Dimensional Soil Water Flow Method}

The one-dimensional soil water flow method can be used in the recharge estimation if suitable models for the boundary conditions are provided (Simmers 1987). The general one-dimensional equation can be written as:

$$
\frac{\partial \theta}{\partial t}=-\frac{\partial}{\partial z}\left[k\left(\frac{\partial S}{\partial z}\right)+1\right]-s
$$

where $\theta=$ volumetric water content $\left(\mathrm{cm}^{3} / \mathrm{cm}^{3}\right), t=$ time $(\mathrm{min}), k=$ the unsaturated conductivity $(\mathrm{cm} / \mathrm{min}), \mathrm{S}=$ soil moisture tension, $z=\operatorname{depth}(\mathrm{cm})$, and $s=\operatorname{sink}$ term $(1 / \mathrm{min})$. The moisture retention $(S)$ can be calculated from the following equation:

$$
\mathrm{S}=\left(\theta-\theta_{r}\right) /\left(\theta s-\theta_{r}\right)
$$

where $\theta s=$ saturated water content and $\theta r=$ residual water content.

The significant advantage of this method is that there are possibilities for studying the areal variability of recharge and the recharge processes and dynamics.

\subsubsection{Inverse Modeling}

The inverse model predicts the recharge rate from the hydraulic head, hydraulic conductivity, etc., based on a two-dimensional finite element (or finite difference) groundwater model $[26,50,59]$. In this method, the ratio of recharge with the hydraulic conductivity is estimated; thus, the estimate's accuracy depends on the hydraulic conductivity data. A nonlinear regression between a simulation and the measured values is evaluated. This is achieved either by a trial-and-error method or by a direct approach that treats the parameter as dependent variables.

\section{Groundwater Scenario and Aquifer Systems in India}

As mentioned in the introduction, India is one of the most significant groundwater users, mainly for drinking, domestic, and irrigational purposes. A drastic increase in groundwater extraction has been observed in the past five decades in India. Shah et al. [60] reported that in this period, groundwater use increased from 100 million $\mathrm{m}^{3}$ (1950) to $1000 \mathrm{~m}^{3}$ (2000) due to development in the agricultural, infrastructure, and industrial sectors. Developments in technology provided easy access to dug and bore wells to more people. It is evident from the increase in the number of wells from 3.86 to 4.75 million during 40 years from 1950 to $1990[61,62]$. The introduction of deep borewells is becoming a serious threat to deep groundwater resources.

India's hydrogeological settings can be generally classified as porous formation and fissured formations. The hard-fissured formations include crystalline, trappean basalt, and consolidated sedimentary rocks [63]. In the central part of the country, alluvial formations are observed. The aquifers in India can be classified as alluvial aquifers, laterite aquifers, sandstone-shale aquifers, limestone aquifers, basalt aquifers, and crystalline aquifers.

Alluvial aquifers comprise recent alluvium, older alluvium, and aeolian and coastal deposits. The composition of these sediments is principally sand, silt, clay, pebbles, etc. These aquifers are the most crucial groundwater reserve, and the most critical example is the Indo-Gangetic plain. Another important aquifer system is formed by the laterite, formed by the chemical weathering of parent rocks in the tropical regions. These are extensively developed aquifers in the peninsular states of India [63]. They are found mainly along valleys and topographically low-lying areas. Sandstone shale aquifers are developed in the Gondwana System and tertiary deposits along peninsular India's east and west coasts. Limestone aquifers are consolidated sedimentary rocks such as limestones, dolomite, and 
marble. These aquifers have fracture zone and cavities by solution activities that act as the water-bearing zones. Cuddapah and Vindhyan subgroups and their equivalents are the largest limestone and dolomite aquifers. Basaltic formations are usually observed in the decan trap area. They have alternate layers of compact and vesicular beds of lava flows. The water-bearing zones are the weathered and fractured zones. The permeability of these formations is medium, and thus, the groundwater occurrence is controlled by the nature and extent of their weathering, the presence of vesicles and lava tubes, and the thickness, the number of flows, and the nature of inter-trappean layers. Crystalline aquifers mainly comprise granite, gneisses, and high-grade metamorphic rocks. Groundwater occurrence and its distribution are controlled by weathered rocks and fractures, joints, and bedding planes. In this formation, groundwater is mainly in a semi-confined or confined state.

In general, the aquifers of India can be classified based on the size of aquifers and groundwater potential as unconsolidated, semi-consolidated, and consolidated formations and hilly formations. Unconsolidated alluvial formations cover the Indo-Gangetic and Brahmaputra plains, coastal aquifers, and desert regions of Rajasthan and Gujarat on India's eastern and west coasts with very high groundwater reserves. This region is mainly composed of the Indus-Ganges-Brahmaputra (IGB), considered the most productive aquifer system in India [64]. Semi-consolidated and consolidated formations with consolidated sedimentary formations, basalts, and crystalline rocks found in peninsular India. In these regions, the groundwater is available at shallow depths. The volcanic aquifers (basalt) are mainly occurring in Deccan traps, with a large geographic extend of $500,000 \mathrm{~km}^{2}$. Mountainous aquifer systems are present in hilly states, always connected to springs and streams. Pore systems have lengthy interconnections, and water travels longer distances [65]. A map of the aquifer systems in India is provided in Figure 1. 


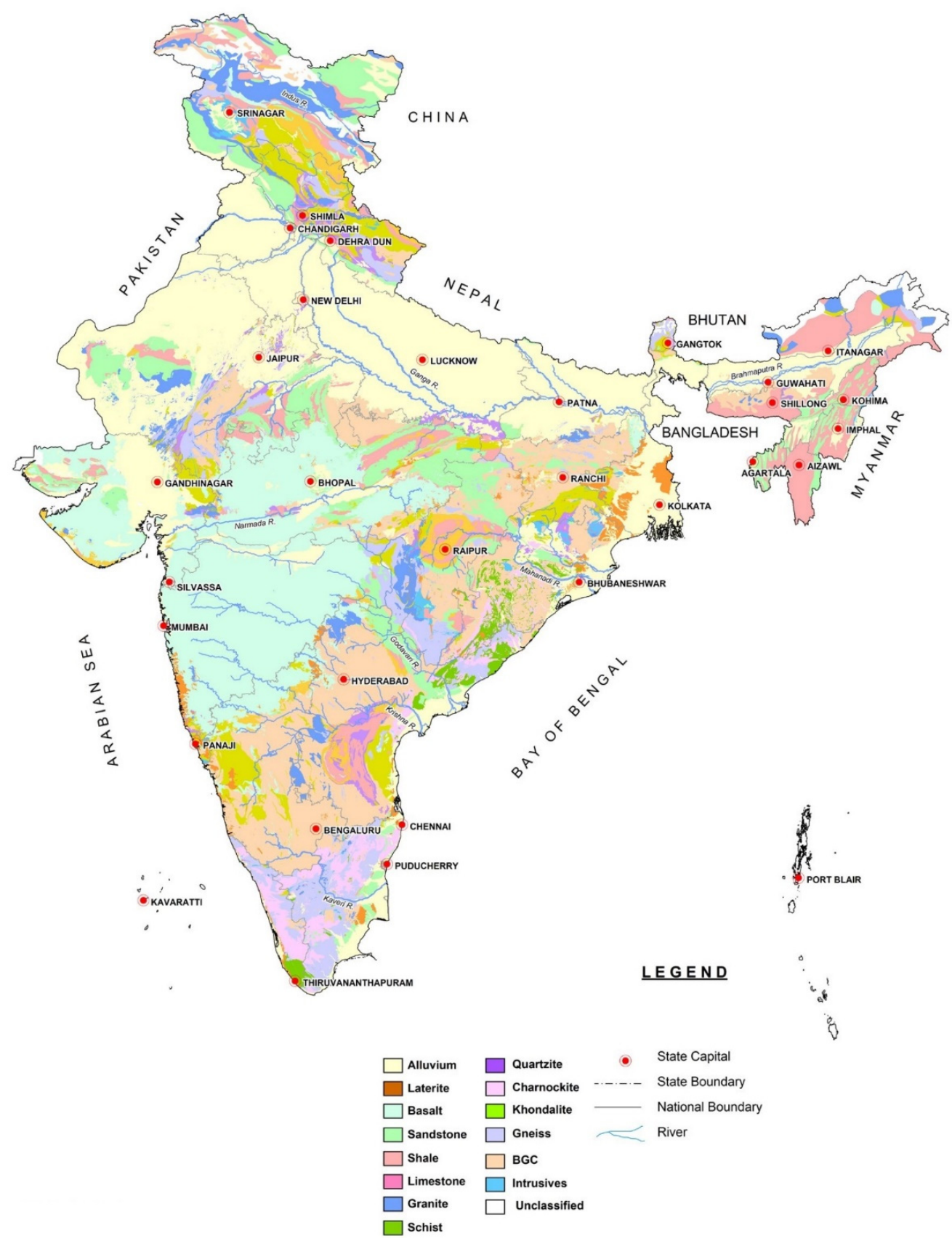

Figure 1. Map showing aquifer systems in India (adopted from CGWB 2014 [64]).

\section{Historical Background for Groundwater Recharge Estimation in India}

Surface water resource estimation using empirical methods started in India during the 19th century. Though groundwater is a widely used resource, it took a few decades to estimate the groundwater resources scientifically. Evidence for an empirical approach by the Chaturvedi formula in 1936 is reported in Kumar and Seethapathi (2007), who estimated the recharge in the Ganga-Yamuna doab using water level fluctuations and precipitation data. There was a modification suggested by the UP-Irrigation Research Institute, Roorkee.

The original Chaturvedi method can be calculated using the following equation:

$$
R=2.0(P-15)^{0.4}
$$


The modified equation can be written as:

$$
R=1.35(P-14)^{0.5}
$$

where $R=$ net recharge due to precipitation (in inches) and $P=$ annual precipitation.

Later in 1949, Khosla developed a method to estimate surface water resources suitable for Indian conditions [66]. This method is based on monthly evaporation loss in inches $\left(L_{m}\right)$ and mean monthly temperature $\left(T_{m}\right)$, calculated as follows:

$$
L_{m}=\left(T_{m}-32\right) / 9.5
$$

A guideline circulated in 1972 among the respective organizations with norms for groundwater estimation in India [67]. Apart from these approaches, different departments started to estimate countries' groundwater resources; however, unavailability of scientific data and poor understanding of the recharge and discharge process has resulted in erroneous approximation [68]. The first scientific approach was by the Groundwater Over Exploitation Committee in 1979. Later, in 1982, the Groundwater Estimation Committee (GEC) was formed with various governmental and educational institutions members. Since its formation, this committee has stood as a regulating authority for groundwater estimation in India. The formal guidelines for recharge estimation came into existence in 1984 [66]. Since then, this committee has remained the authority making decisions on groundwater estimation in India.

The GEC recommended two methods for recharge estimation, namely, (i) groundwater level fluctuation and specific yield for areas where routine groundwater level monitoring is conducted, and for other regions, (ii) the rainfall infiltration method in areas where water level monitoring is not/poorly performed, and where there is a subsequent lack of accurate data. The groundwater fluctuation and specific yield methods were explained in the earlier section.

In general, monsoon-fed India shows drastic changes in groundwater recharge due to precipitation. The Indian meteorological department (IMD) suggested a formula to represent groundwater recharge during the monsoon season [6]:

$$
\text { Monsoon recharge }=\left(S+D W-R_{s}-R_{\text {igw }}-R_{i s}\right) \times \frac{\text { Normal Monsson } R f}{\text { Annual Monsson } R f} \times R_{s}+R_{i s}
$$

where $S$ = change in groundwater storage volume during the pre- and post-monsoon period, $D W=$ gross groundwater draft during the monsoon season $(\mathrm{mcm})$, and $R s=$ recharge as canal seepage during the monsoon season $(\mathrm{mcm}) . R_{\text {igw }}=$ recharge from groundwater irrigation during the monsoon season, whereas $R=$ represents surface water recharge and $R F=$ rainfall (meter).

\section{Critical Review of Groundwater Recharge Estimation Practices in India}

As a versatile country with a wide range of environmental and hydrogeological settings, multiple methods for groundwater recharge estimation are needed in India. Local estimation and later extrapolating the results to the entire region are generally practiced in the large basins, with more efficiency. As per the Groundwater Estimation Committee (GEC), the official recharge estimation methods of the country are the water level fluctuation (WLF) and rainfall infiltration methods. According to reports, the country's groundwater resources are classified based on the exploitation rate into white, gray, and black. Among the 7928 units in total, 425 are considered as more than $85 \%$ exploited, termed the black/critical category, and 673 units are considered as overexploited, with an exploitation level of $65 \%$ to $85 \%$, falling under the gray category. The remaining units are classified as white. We extensively explore in this paper the most common recharge estimation methods and their efficiency. A short review of the literature on groundwater recharge estimation is given in Table 1. 
Table 1. Review of the recharge estimation methods practiced in India.

\section{Reference Title} (Alphabetical)

Sukhija et al., 1988 [69]

Cuddalore Aquifers, Pondichery
Andhra Pradesh
Lower Maner Basin,
Area of Estimate

Tritium injection

\section{Methodology Used Inferences}

- $\quad$ Recharge varies with depth and soil types

- Total annual input to groundwater was $152 \times 10^{6} \pm 15 \times 10^{6} \mathrm{~m}^{3}$, i.e., $8 \%$ of total annual rainfall $(125 \mathrm{~cm})$

- $\quad$ Recharge values were comparable with physical methods

- Recharge rates-for Cuddalore $26 \mathrm{~cm} /$ year and $22 \mathrm{~cm} /$ year; for alluvium, $10 \mathrm{~cm} /$ year and $14 \mathrm{~cm} /$ year estimated for tritium and chloride methods, respectively

- Validity of the chloride method for semiarid tropical coastal successfully demonstrated

- $\quad$ The average groundwater recharge was $86.7 \mathrm{~mm} /$ year for an average annual rainfall of $759.6 \mathrm{~mm}$.
Kanchanapally

Srinivas et al., 1999 [70]
$11 \mathrm{~km}^{2}$

Pradesh
Water bal-

ance/groundwater

flow model
- Monthly recharge estimates were found useful for accounting dynamic temporal variations

- Net recharge estimated as 2.54 MMC, still water level falls $0.79 \mathrm{~m}$

Three blocks in Karim

Rao and Chakraborti, 2000 [71] Nagar Dt. Andhra Pradesh
Semi-empirical water balance model/RS
- Waterlogging contributes an increase in WL of $0.35 \mathrm{~m}$

- Rotational operation of canal and aquifers are suggested

Krishni-Yamuna

Ahmed and Umar, 2008 [72] Micro-watershed,

Uttar Pradesh

$434 \mathrm{~km}^{2}$

Water balance and tritium method
Total recharge in the basin is estimated as $185.25 \mathrm{MCM}$
Prasad and Rastogi, 2001 [73]

Mahi Right Bank

Canal project area
$2997 \mathrm{~km}^{2}$

Numerical/inverse model
- Net annual recharge estimated as 741.97 MCM

- Supremacy of genetic algorithm on numerical modeling method, when using noisy data, is proved

- $\quad$ Recharge is found to be proportional to Injected tritium depth to basement, degree of tracer and geo-electric methods and sand content

- $\quad$ Natural recharge found to be 0 to $200 \mathrm{~mm}$

- Simple, practical, and less expensive method

Chand et al., 2005 [74]

Hayat Nagar Micro-watershed

$0.045 \mathrm{~km}^{2}$

Neutron moisture probe
Recharge due to water level rise is estimated as 0.22 to 0.37 , with an average of $0.30 \mathrm{~m}$, which is equivalent to $0.0135 \mathrm{MCM}$

- $\quad$ Estimated groundwater recharge from rainfall by WTF is $7.3 \%$ (2003) and $9.7 \%$ (2004), whereas by CMB method, it was $7.5 \%$ ( 2 year average value)

Water table fluctuation (WTF)/chloride mass balance (CMB)
Showing the need of at least $104.3 \mathrm{~mm}$ cumulative rainfall for making $1 \mathrm{~mm}$ recharge by storage structures 
Table 1. Cont.

\begin{tabular}{|c|c|c|c|c|}
\hline $\begin{array}{l}\text { Reference Title } \\
\text { (Alphabetical) }\end{array}$ & Location & $\begin{array}{l}\text { Area of } \\
\text { Estimate }\end{array}$ & Methodology Used & Inferences \\
\hline Saha and Agarwal, 2006 [76] & $\begin{array}{l}\text { Torla Odha watershed, } \\
\text { Maharashtra }\end{array}$ & $22.05 \mathrm{~km}^{2}$ & $\begin{array}{l}\text { Water bal- } \\
\text { ance/groundwater } \\
\text { budgeting }\end{array}$ & 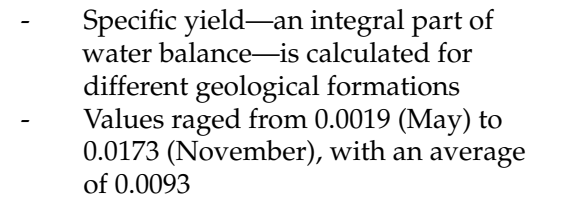 \\
\hline Thomas et al., 2009 [77] & $\begin{array}{l}\text { Sagar Block, } \\
\text { Madhya Pradesh }\end{array}$ & $847.47 \mathrm{~km}^{2}$ & Water balance & $\begin{array}{l}\text { - } \quad \text { Rainfall recharge in monsoon season in } \\
\text { the range of } 122.45 \text { and } 183.71 \mathrm{MCM} \\
\text { - } \quad \text { Declining trends were found in the } \\
\text { groundwater storage }\end{array}$ \\
\hline Rangarajan et al., 2009 [19] & $\begin{array}{l}\text { SIIL watershed, } \\
\text { Tuticorin, Tamil Nadu }\end{array}$ & $112 \mathrm{~km}^{2}$ & $\begin{array}{l}\text { Tracer/pumping } \\
\text { test methods }\end{array}$ & $\begin{array}{l}\text { - } \quad \text { Rainfall recharge is estimated as an } \\
\text { average } 61.7 \mathrm{~mm} \text {, i.e., } 10.6 \% \text { of the } \\
\text { rainfall in the study period } \\
\text { - Specific yields for different formations } \\
\text { were measured, water level } \\
\text { fluctuations were correlated with the } \\
\text { recharges estimates }\end{array}$ \\
\hline Singhal et al., 2010 [78] & $\begin{array}{l}\text { Pathri Rao watershed, } \\
\text { Uttarakhand }\end{array}$ & $52 \mathrm{~km}^{2}$ & $\begin{array}{l}\text { Geo- } \\
\text { electrical/isotope }\end{array}$ & $\begin{array}{l}\text { - Groundwater recharge vs. } \\
\text { development was in the order of } \\
19 \% \text { vs. } 164 \% \\
\text { - Critical over-exploitation of } \\
\text { groundwater is reported }\end{array}$ \\
\hline Ajay Singh, 2011 [79] & Haryana India & $44,212 \mathrm{~km}^{2}$ & $\begin{array}{l}\text { Hydrological } \\
\text { budget model }\end{array}$ & 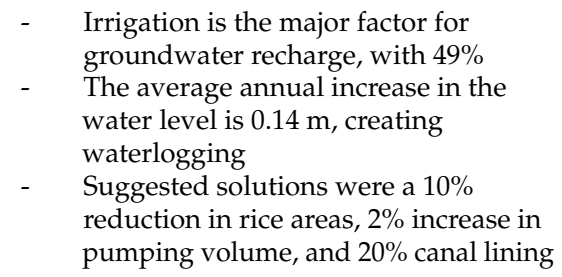 \\
\hline Rawat et al., 2012 [80] & $\begin{array}{l}\text { Shankergarh block of } \\
\text { Allahabad }\end{array}$ & $\mathrm{km}^{2}$ & $\begin{array}{l}\text { Water } \\
\text { balance/empirical } \\
\text { formula/RS-GIS }\end{array}$ & $\begin{array}{l}\text { - } \quad \text { Groundwater recharge is } 393 \mathrm{~mm} / \text { year, } \\
\text { mostly in rainy season } \\
\text { - } \quad \text { Runoff }(880.35) \text { is two times or more } \\
\text { than the actual recharge value }\end{array}$ \\
\hline
\end{tabular}

\section{Selection of Suitable Recharge Estimation Methods}

Estimation of recharge with any method is subject to a high amount of uncertainty and error. Choosing a suitable method is often dependent on the study's objective, whether to monitor paleo-recharge, long-term average recharge values, annual or monthly recharge estimates, area of estimation (aquifer/watershed/basin level), or spatial variation of recharge [81,82]. The chosen recharge method must address the complexity of geological formations, flow process, erratic nature of precipitation, the conversion rate of total input water to effective recharge, improvement of estimation practices, and the accuracy of data. The major classification of suitable methods can be based on climate, recharge rate and area of estimation, aquifer parameters, and hydrogeological settings.

Climate is important to choose the proper methodology for a given area. The methods used in semiarid/arid regions would not be effective in humid regions. For example, in arid regions, the observation wells monitoring the water table will typically be less frequent. Lack of data will force interpolation, which often causes errors [43]. In India, the monsoon season plays a significant role in groundwater recharge. The water table variation in pre- and post-monsoon seasons allows using the water table fluctuation method for the estimation [65]. The zero-flux plane was suggested in the unsaturated aquifers, other than the water table fluctuation method, and lysimeters. Tracers, age dating, and numerical modeling will be suitable for both saturated and unsaturated zones $[26,83,84]$. 
Space and time considerations are important and significantly impact choosing appropriate recharge estimates [81]. Spatially, the estimates can be point/local estimates or regional estimates. Point estimates are more accurate but often unable to represent the characteristics of the whole basin. On the other hand, regional estimates can represent a large geographical area but may give a generalized estimation [84]. Chand et al. [74] successfully used a neutron moisture probe in a micro-watershed to estimate groundwater recharge. Numerical model-based estimates are effective in representing large geographical areas. However, it is suggested that the consistency of the model parameters must be examined [26]. Watershed modeling was also suggested as a suitable method for large areas. In case of a time constraint, it is always advisable for a short-term estimation to pair with tracer techniques, because for this method, a single sampling is enough and can provide an average recharge estimate over several years [81].

The limited access to climatic data is usually a problem in the estimation of recharge. Either the data will not be available throughout the application site because of a lack of a monitoring station, or because of other errors associated with monitoring. The other issue is that the scientific monitoring of the climatic variable is stated at the beginning of the 19th century, so no prior date is available for historical monitoring recharge. Spatial variation of the recharge is essential in the case of groundwater vulnerability studies [84,85]. In addition, physical methods such as water table fluctuation need a high data density. For long-term variation analysis of recharge, it is suggested to use isotopic techniques.

Availability of resources is a primary concern in choosing the methods. Financial constraints will be another issue that prevents researchers from using sophisticated methods. For example, isotopic tracers are helpful in many cases, but the analytical procedure involved in this method needs modern laboratory facilities and a big budget. On the other hand, the cost of estimation is not an indication of the method's accuracy. Unavailability of data is another problem often encountered in hydrologic analysis. Unavailability may lead to the use of data of different spatial and temporal scales [86].

For India, it is recommended to estimate the recharge seasonally in pre- and postmonsoon seasons. The water balance approach is a very effective method in establishing the rainfall recharge coefficient and evaluating the methods adopted for quantifying discharge and recharge from other sources [66]. In semiarid regions with certain conditions and assumptions, chloride mass balance has been found to supplement sensible groundwater recharge estimates, potentially comparable to other classical physical measurement techniques $[36,75,87]$. The water table fluctuation method is the most widely used and recommended method for Indian conditions because of the straightforward estimation and comparatively lower parameters and data needed. An important delimiting factor is difficulty in determining a representative value of storability (S) for the entire study area. However, the major drawback is that lateral flow is not considered, which is assumed as zero.

As all methods have their own limitations, the best possible solution is to choose multiple methods $[26,31,88]$. The use of multiple methods helps to understand the measurement errors and problems which arise in the assumptions and thus permit the revision of the conceptual model. The best part is that many methods use similar datasets to derive the recharge estimate; thus, the use of different methods can occur without additional data collection. Several examples available in the literature benefited from using multiple methods. Delin et al. [86] used four different techniques: (1) unsaturated zone water balance (UZWB), which utilizes soil-moisture data, (2) water table fluctuations (WTF), (3) age dating of water in the saturated zone, and (4) RORA, a basin-scale analysis of streamflow records using a recession curve displacement technique to quantify the regional scale estimation of the recharge in Minnesota, USA. Ebrahimi et al. [89] used inverse modeling coupled with remote sensing to study the groundwater recharge in the Mosian aquifer in the west of Iran. In India, multiple method estimation was reported by several researchers. The surface resistivity method and isotope technique were used by Israil et al. [12] to estimate recharge in the Himalayas. In another study, water table fluctuation, chloride mass balance, and storage balance were used by Sarda et al. [75], and many more studies of this kind 
are reported. Based on the literature and the hydrological-climatic conditions, suitable methods for different regions of India are presented in Table 2.

Table 2. Suitable estimation method for groundwater recharge in India.

\begin{tabular}{|c|c|c|c|}
\hline \multirow[t]{2}{*}{ Hydrologic Zone } & \multicolumn{3}{|c|}{ Appropriate Techniques for Different Climates } \\
\hline & Arid/Semi-Arid & Tropical/Sub-Tropical & Humid/Mountainous \\
\hline Unsaturated zone & $\begin{array}{c}\text { Zero-flux plane } \\
\text { Historical and } \\
\text { environmental tracers } \\
\text { Numerical modeling }\end{array}$ & $\begin{array}{c}\text { Water table } \\
\text { fluctuation (WTF) } \\
\text { Zero-flux plane } \\
\text { Soil water balance model }\end{array}$ & $\begin{array}{l}\text { Isotropic tracers } \\
\text { Darcy's law } \\
\text { Lysimeters }\end{array}$ \\
\hline Saturated zone & $\begin{array}{l}\text { Historical and } \\
\text { environmental tracers } \\
\text { Numerical modeling }\end{array}$ & $\begin{array}{c}\text { Isotopic tracers } \\
\text { Numerical modeling }\end{array}$ & $\begin{array}{c}\text { Water table } \\
\text { fluctuation (WTF) } \\
\text { Numerical modeling } \\
\text { Darcy's law }\end{array}$ \\
\hline
\end{tabular}

\section{Conclusions}

Groundwater recharge estimation is vital in regions such as India, where the water supply is mainly dependent on groundwater. Groundwater resources in India are highly exploited and vulnerable to pollution. In this review, we evaluated aquifer systems in India and the key factors that affect groundwater recharge. Aquifer systems in India mostly comprise alluvial systems and crystalline rocks. Generally, choosing the most suitable method for estimation is based on many factors, such as the objective of the study, whether to monitor in the long term or short term, space constraints, climatic conditions, availability of reliable data, etc. If the study needs to address large areas, numerical modeling or watershed modeling is suggested. In unconfined aquifers, water table fluctuation methods and water balance methods are found to be effective. Tracer techniques have applications in both saturated and unsaturated formations. Climate-based databases have been recorded only for the last 100 years. Thus, for a more extended estimation period, data will not be available. In this case, physical methods will not be effective. Recharge estimate in India started at the beginning of the 19th century and began a long tradition. The Groundwater Estimation Committee (GEC) of the Indian government suggested water table fluctuation as the most suitable method. Because of the monsoons, this method gives a cost-effective and reliable result, under the condition that rainwater is the only source. The application of both point estimation methods and regional estimation methods were found in the literature for India. We suggest suitable recharge estimate techniques for India based on hydrologic and climatic conditions. The use of multiple methods for the same area is recommended to evaluate the accuracy of the methods and provide an opportunity to compare the results and reach a conclusion. This paper provides valuable information on selecting the suitable recharge methods for different hydro-geo-climatic conditions, saving time, money, and human effort in the initial planning of recharge estimation. Additionally, the results described in this study can be easily replicated elsewhere with similar conditions.

Author Contributions: Conceptualization, P.J.S.K.; writing-original draft preparation, P.J.S.K.; writing-review and editing, P.J.S.K., M.S. and L.E.; supervision, M.S. and L.E. All authors have read and agreed to the published version of the manuscript.

Funding: The publication of this article was funded by Freie Universität Berlin.

Conflicts of Interest: The authors declare no conflict of interest.

\section{References}

1. Saha, D.; Ray, R.K. Groundwater resources of India: Potential, challenges and management. In Groundwater Development and Management; Springer: Berlin/Heidelberg, Germany, 2019; pp. 19-42.

2. The UN General Assembly (UNGA). Resolution Adopted by the General Assembly on 28 July 2010. 64/292. The Human Right to Water and Sanitation. Available online: https://undocs.org/pdf?symbol=en/a/res/64/292 (accessed on 10 November 2021). 
3. The UN General Assembly (UNGA). The Human Right to Safe Drinking Water and Sanitation; UNGA: Geneva, Switzerland, 2014; Resolution 68/157/2013; Available online: https:/ / undocs.org/pdf?symbol=en/A/RES/68/157 (accessed on 11 November 2021).

4. Gandhi, V.P.; Namboodiri, N. Groundwater Irrigation in India: Gains, Costs and Risks. 2009. Available online: http://www iimahd.ernet.in/publications/data/2009-03-08Gandhi.pdf (accessed on 1 June 2014).

5. CGWB. Dynamic Groundwater Resources of India, as on 31 March 2013, Central Ground Water Board, Ministry of Water Resources. River Development and Ganga Rejuvenation. Government of India, Faridabad. 2017. Available online: http:/ / cgwb.gov.in/Documents/ Dynamic-GW-Resources-2011.pdf (accessed on 15 June 2018).

6. CGWB. Status Report on Review of Ground Water Resources Estimation Methodology. 2009. Available online: http://cgwb.gov in/documents/gec97.pdf (accessed on 12 April 2017).

7. Guevara-Ochoa, C.; Medina-Sierra, A.; Vives, L. Spatio-temporal effect of climate change on water balance and interactions between groundwater and surface water in plains. Sci. Total Environ. 2020, 722, 137886. [CrossRef] [PubMed]

8. Mojid, M.A.; Parvez, M.F.; Mainuddin, M.; Hodgson, G. Water Table Trend-A Sustainability Status of Groundwater Development in North-West Bangladesh. Water 2019, 11, 1182. [CrossRef]

9. de Vries, J.J.; Simmers, I. Groundwater recharge: An overview of processes and challenges. Hydrogeol. J. 2002, 10, 5-17. [CrossRef]

10. Ruiz, L.; Varma, M.R.R.; Kumar, M.S.M.; Sekhar, M.; Maréchal, J.-C.; Descloitres, M.; Riotte, J.; Kumar, S.; Kumar, C.; Braun, J.-J Water balance modelling in a tropical watershed under deciduous forest (Mule Hole, India): Regolith matric storage buffers the groundwater recharge process. J. Hydrol. 2010, 380, 460-472. [CrossRef]

11. Uc, C.J.L.; Leal, J.A.R.; Cruz, D.A.M.; Martínez, A.C.; Celestino, A.E.M. Identification of the Dominant Factors in Groundwater Recharge Process, Using Multivariate Statistical Approaches in a Semi-Arid Region. Sustainability 2021, $13,11543$.

12. Israil, M.; Al-Hadithi, M.; Singhal, D.C.; Kumar, B. Groundwater-recharge estimation using a surface electrical resistivity method in the Himalayan foothill region, India. Hydrogeol. J. 2006, 14, 44-50. [CrossRef]

13. Singh, A. Long-Term (44 Years) Regional Groundwater Recharge Estimation for Agricultural Sustainability. Nat. Resour. Res. 2021, 1-11. [CrossRef]

14. Asoka, A.; Wada, Y.; Fishman, R.; Mishra, V. Strong Linkage Between Precipitation Intensity and Monsoon Season Groundwater Recharge in India. Geophys. Res. Lett. 2018, 45, 5536-5544. [CrossRef]

15. Allison, G.B.; Gee, G.W.; Tyler, S.W. Vadose-Zone Techniques for Estimating Groundwater Recharge in Arid and Semiarid Regions. Soil Sci. Soc. Am. J. 1994, 58, 6-14. [CrossRef]

16. Schilling, O.S.; Parajuli, A.; Tremblay Otis, C.; Müller, T.U.; Antolinez Quijano, W.; Tremblay, Y.; Brennwald, M.S.; Nadeau, D.F.; Jutras, S.; Kipfer, R.; et al. Quantifying Groundwater Recharge Dynamics and Unsaturated Zone Processes in Snow-Dominated Catchments via On-Site Dissolved Gas Analysis. Water Resour. Res. 2021, 57, e2020WR028479. [CrossRef]

17. Pan, Y.; Gong, H.; Zhou, D.; Li, X.; Nakagoshi, N. Impact of land use change on groundwater recharge in Guishui River Basin, China. Chin. Geogr. Sci. 2011, 21, 734-743. [CrossRef]

18. Hughes, A.; Mansour, M.; Ward, R.; Kieboom, N.; Allen, S.; Seccombe, D.; Charlton, M.; Prudhomme, C. The impact of climate change on groundwater recharge: National-scale assessment for the British mainland. J. Hydrol. 2021, 598, 126336. [CrossRef]

19. Rangarajan, R.; Athavale, R.N. Annual replenishable ground water potential of India-An estimate based on injected tritium studies. J. Hydrol. 2000, 234, 38-53. [CrossRef]

20. Paul, S.; Ghosh, S.; Mathew, M.; Devanand, A.; Karmakar, S.; Niyogi, D. Increased Spatial Variability and Intensification of Extreme Monsoon Rainfall due to Urbanization. Sci. Rep. 2018, 8, 3918. [CrossRef] [PubMed]

21. World Bank. India Groundwater: A Valuable but Diminishing Resource. 2012. Available online: http://www.worldbank.org/en/ news / feature/2012/03/06/india-groundwater-critical-diminishing (accessed on 25 October 2017).

22. Narain, S. Sanitation for all. Nature 2012, 486, 185. [CrossRef] [PubMed]

23. Sha, M. A 21st Century Institutional Architecture for India's Water Reforms; CWC: New Delhi, India; CGWB: New Delhi, India, 2016; p. 146.

24. Saha, D.; Marwaha, S.; Mukherjee, A. Groundwater resources and sustainable management issues in India. In Clean and Sustainable Groundwater in India; Springer: Berlin/Heidelberg, Germany, 2018; pp. 1-11.

25. Kumar Joshi, S.; Gupta, S.; Sinha, R.; Logan Densmore, A.; Prakash Rai, S.; Shekhar, S.; Mason, P.J.; Dijk, W.M.V. Strongly heterogeneous patterns of groundwater depletion in Northwestern India. J. Hydrol. 2021, 598, 126492. [CrossRef]

26. Scanlon, B.R.; Healy, R.W.; Cook, P.G. Choosing appropriate techniques for quantifying groundwater recharge. Hydrogeol. J. 2002, 10, 18-39. [CrossRef]

27. Khalil, M.; Sakai, M.; Mizoguchi, M.; Miyazaki, T. Current and prospective applications of zero flux plane (ZFP) method. J. Jpn. Soc. Soil Phys. 2003, 95, 75-90.

28. Krishnaswamy, J.; Bonell, M.; Venkatesh, B.; Purandara, B.K.; Rakesh, K.N.; Lele, S.; Kiran, M.C.; Reddy, V.; Badiger, S. The groundwater recharge response and hydrologic services of tropical humid forest ecosystems to use and reforestation: Support for the "infiltration-evapotranspiration trade-off hypothesis". J. Hydrol. 2013, 498, 191-209. [CrossRef]

29. Thornthwaite, C.W. An Approach toward a Rational Classification of Climate. Geogr. Rev. 1948, 38, 55. [CrossRef]

30. Healy, R.W.; Cook, P.G. Using groundwater levels to estimate recharge. Hydrogeol. J. 2002, 10, 91-109. [CrossRef]

31. Nimmo, J.R.; Healy, R.W.; Stonestrom, D.A. Aquifer Recharge. In Encyclopedia of Hydrological Sciences; Anderson, M.G., McDonnell, J.J., Eds.; John Wiley \& Sons: Hoboken, NJ, USA, 2005. [CrossRef]

32. Lerner, D.; Issar, A.S.; Simmers, I. Groundwater recharge. In A Guide to Understanding and Estimating Natural Recharge. International Contributions to Hydrogeology. International Association of Hydrogeologists; Taylor and Francis, Balkema: Rotterdam, The Netherlands, 1990. 
33. Zimmermann, U.; Münnich, K.; Roether, W.; Kreutz, W.; Schubach, K.; Siegel, O. Tracers determine movement of soil moisture and evapotranspiration. Science 1966, 152, 346-347. [CrossRef]

34. Dincer, T.; Al-Mugrin, A.; Zimmermann, U. Study of the infiltration and recharge through the sand dunes in arid zones with special reference to the stable isotopes and thermonuclear tritium. J. Hydrol. 1974, 23, 79-109. [CrossRef]

35. Athavale, R.N.; Murti, C.S.; Chand, R. Estimation of recharge to the phreatic aquifers of the Lower Maner Basin, India, by using the titrium injection method. J. Hydrol. 1980, 45, 185-202. [CrossRef]

36. Wood, W.W.; Sanford, W.E. Chemical and Isotopic Methods for Quantifying Ground-Water Recharge in a Regional, Semiarid Environment. Groundwater 1995, 33, 458-468. [CrossRef]

37. Chand, R.; Chandra, S.; Rao, V.A.; Singh, V.S.; Jain, S.C. Estimation of natural recharge and its dependency on sub-surface geoelectric parameters. J. Hydrol. 2004, 299, 67-83. [CrossRef]

38. Edson, T. Tracer Studies and groundwater Recharge Assessment in the Eastern Fringe of the Botswana Kalahari. Ph.D. Thesis, Vrije Universiteit, Amsterdam, The Netherlands, 1998.

39. Wang, B.; Jin, M.; Nimmo, J.R.; Yang, L.; Wang, W. Estimating groundwater recharge in Hebei Plain, China under varying land use practices using tritium and bromide tracers. J. Hydrol. 2008, 356, 209-222. [CrossRef]

40. Edmunds, W.M.; Gaye, C.B. Estimating the spatial variability of groundwater recharge in the Sahel using chloride. J. Hydrol. 1994, 156, 47-59. [CrossRef]

41. Allison, G.; Hughes, M. The use of environmental chloride and tritium to estimate total recharge to an unconfined aquifer. Soil Res. 1978, 16, 181-195. [CrossRef]

42. Edmunds, W.; Darling, W.; Kinniburgh, D. Solute profile techniques for recharge estimation in semi-arid and arid terrain. In Estimation of Natural Groundwater Recharge; Springer: Berlin/Heidelberg, Germany, 1988; pp. 139-157.

43. Kinzelbach, W.; Aeschbach, W. A Survey of Methods for Analysing Groundwater Recharge in Arid and Semi-Arid Regions; Division of Early Warning and Assessment, United Nations Environment Programme: Nairobi, Kenya, 2002.

44. Vogel, J.C.; Thilo, L.; Van Dijken, M. Determination of groundwater recharge with tritium. J. Hydrol. 1974, 23, 131-140. [CrossRef]

45. Yeh, H.-F.; Lee, C.-H.; Hsu, K.-C.; Chang, P.-H.; Wang, C.-H. Using stable isotopes for assessing the hydrologic characteristics and sources of groundwater recharge. J. Environ. Eng. Manag. 2009, 19, 185-191.

46. Shahul Hameed, A.; Resmi, T.R.; Suraj, S.; Warrier, C.U.; Sudheesh, M.; Deshpande, R.D. Isotopic characterization and mass balance reveals groundwater recharge pattern in Chaliyar river basin, Kerala, India. J. Hydrol. Reg. Stud. 2015, 4, 48-58. [CrossRef]

47. Chen, X.; Huang, Y.; Ling, M.; Hu, Q.; Liu, B. Numerical modeling groundwater recharge and its implication in water cycles of two interdunal valleys in the Sand Hills of Nebraska. Phys. Chem. Earth Parts A B C 2012, 53-54, 10-18. [CrossRef]

48. Hsieh, C.-I.; Katul, G.; Chi, T.-W. An approximate analytical model for footprint estimation of scalar fluxes in thermally stratified atmospheric flows. Adv. Water Resour. 2000, 23, 765-772. [CrossRef]

49. Sophocleous, M. Interactions between groundwater and surface water: The state of the science. Hydrogeol. J. 2002, 10, 52-67. [CrossRef]

50. Sanford, W. Recharge and groundwater models: An overview. Hydrogeol. J. 2002, 10, 110-120. [CrossRef]

51. Winter, T.C. The concept of hydrologic landscapes1. JAWRA J. Am. Water Resour. Assoc. 2001, 37, 335-349. [CrossRef]

52. Šimçnek, J.; Šejna, M.; Van Genuchten, M.T. The HYDRUS-1D Software Package for Simulating the One-Dimensional Movement of Water, Heat, and Multiple Solutes in Variably-Saturated Media. Available online: https://www.ars.usda.gov/arsuserfiles/20 360500/pdf_pubs/P2119.pdf (accessed on 1 March 2020).

53. Chen, X.; Zhang, Z.-C.; Zhang, X.-N.; Chen, Y.-Q.; Qian, M.-K.; Peng, S.-F. Estimation of Groundwater Recharge from Precipitation and Evapotranspiration by Lysimeter Measurement and Soil Moisture Model. J. Hydrol. Eng. 2008, 13, 333-340. [CrossRef]

54. Shamsi, E.; Ziaei, A.N.; Naghedifar, S.M.R.; Ansary, H. Groundwater Recharge Assessment of Different Irrigation Scenarios by Using Unsaturated Zone Modeling (Case Study: Neishabour Plain). Iran. J. Soil Water Res. 2020, 51, 311-323.

55. Zeinali, M.; Azari, A.; Heidari, M.M. Simulating unsaturated zone of soil for estimating the recharge rate and flow exchange between a river and an aquifer. Water Resour. Manag. 2020, 34, 425-443. [CrossRef]

56. Yeh, T.-C.J.; Mao, D.-Q.; Zha, Y.-Y.; Wen, J.-C.; Wan, L.; Hsu, K.-C.; Lee, C.-H. Uniqueness, scale, and resolution issues in groundwater model parameter identification. Water Sci. Eng. 2015, 8, 175-194. [CrossRef]

57. Knowling, M.J.; Werner, A.D. Estimability of recharge through groundwater model calibration: Insights from a field-scale steady-state example. J. Hydrol. 2016, 540, 973-987. [CrossRef]

58. Yu, K.C.; Hong, L.D.; Liu, C.Y. Solving Transient Groundwater Inverse Problems Using Space-Time Collocation Trefftz Method. Water 2020, 12, 3580 .

59. Markus, W.; Houben, G.; Lohe, C.; Quinger, M.; Himmelsbach, T. Inverse Modeling and Uncertainty Analysis of Potential Groundwater Recharge to the Confined Semi-Fossil Ohangwena Ii Aquifer, Namibia. Hydrogeol. J. 2017, $25,2303-2321$.

60. Shah, T.; Bruke, J.; Vullholth, K.; Angelica, M.; Custodio, E.; Daibes, F.; Van Dijk, J.H.; Giordano, M.; Girman, J.; Van Der Gun, J. Groundwater: A global assessment of scale and significance. In Water for Food Water for Life: A Comprehensive Assessment of Water Management in Agriculture; Earthscan: London, UK, 2007; pp. 395-423.

61. Muralitharan, D.; Athavale, R. Base Paper on Artificial Recharge in India: National Geophysical Research Institute; CSRI: Hyderabad, India, 1998; p. 67.

62. Sakthivadivel, R. The groundwater recharge movement in India. Agric. Groundw. Revolut. Oppor. Threat. Dev. 2007, 3, 195-210.

63. CGWB. Principal Aquifer Systems of India, 2014. Available online: http:/ / cgwb.gov.in/AQM/India.pdf (accessed on 8 September 2019). 
64. Mukherjee, A.; Saha, D.; Harvey, C.F.; Taylor, R.G.; Ahmed, K.M.; Bhanja, S.N. Groundwater systems of the Indian Sub-Continent. J. Hydrol. Reg. Stud. 2015, 4, 1-14. [CrossRef]

65. Kulkarni, H.; Shah, M.; Vijay Shankar, P.S. Shaping the contours of groundwater governance in India. J. Hydrol. Reg. Stud. 2015, 4, 172-192. [CrossRef]

66. Kumar, C.; Seethapathi, P. Assessment of natural groundwater recharge in Upper Ganga Canal command area. J. Appl. Hydrol. 2002, 15, 13-20.

67. Sinha, B.; Sharma, S.K. Natural ground water recharge estimation methodologies in India. In Estimation of Natural Groundwater Recharge; Springer: Berlin/Heidelberg, Germany, 1988; pp. 301-311.

68. CGWB. Report of the Ground Water Resource Estimation Committee (GEC-2015). Available online: http:/ / cgwb.gov.in/Documents/ GEC2015_Report_Final\%2030.10.2017.pdf (accessed on 8 September 2019).

69. Sukhija, B.S.; Reddy, D.V.; Nagabhushanam, P.; Chand, R. Validity of the environmental chloride method for recharge evaluation of coastal aquifers, India. J. Hydrol. 1988, 99, 349-366. [CrossRef]

70. Srinivas, A.; Rao, B.V.; Gurunadha Rao, V.V.S. Recharge process and aquifer models of a small watershed. Hydrol. Sci. J. 1999, 44, 681-692. [CrossRef]

71. Rao, V.V.; Chakraborti, A.K. Water balance study and conjunctive water use planning in an irrigation canal command area: A remote sensing perspective. Int. J. Remote Sens. 2000, 21, 3227-3238. [CrossRef]

72. Ahmed, I.; Umar, R. Hydrogeological framework and water balance studies in parts of Krishni-Yamuna interstream area, Western Uttar Pradesh, India. Environ. Geol. 2008, 53, 1723-1730. [CrossRef]

73. Lakshmi Prasad, K.; Rastogi, A.K. Estimating net aquifer recharge and zonal hydraulic conductivity values for Mahi Right Bank Canal project area, India by genetic algorithm. J. Hydrol. 2001, 243, 149-161. [CrossRef]

74. Chand, R.; Mondal, N.; Singh, V. Estimation of groundwater recharge through neutron moisture probe in Hayatnagar microwatershed, India. Curr. Sci. 2005, 89, 396-400.

75. Sharda, V.N.; Kurothe, R.S.; Sena, D.R.; Pande, V.C.; Tiwari, S.P. Estimation of groundwater recharge from water storage structures in a semi-arid climate of India. J. Hydrol. 2006, 329, 224-243. [CrossRef]

76. Saha, D.; Agrawal, A.K. Determination of specific yield using a water balance approach-Case study of Torla Odha watershed in the Deccan Trap province, Maharastra State, India. Hydrogeol. J. 2006, 14, 625-635. [CrossRef]

77. Thomas, T.; Jaiswal, R.K.; Galkate, R.; Singh, S. Development of a Rainfall-Recharge Relationship for a Fractured Basaltic Aquifer in Central India. Water Resour. Manag. 2009, 23, 3101-3119. [CrossRef]

78. Singhal, D.; Israil, M.; Sharma, V.; Kumar, B. Evaluation of groundwater resource and estimation of its potential in Pathri Rao watershed, district Haridwar (Uttarakhand). Curr. Sci. 2010, 98, 162-170.

79. Singh, A. Estimating long-term regional groundwater recharge for the evaluation of potential solution alternatives to waterlogging and salinisation. J. Hydrol. 2011, 406, 245-255. [CrossRef]

80. Rawat, K.S.; Mishra, A.K.; Paul, G.; Kumar, R. Estimation of Ground Water Recharge in Shankergarh block of Allahabad (India) using Remote Sensing and Statistical Approach. Glob. J. Sci. Eng. Technol. 2012, 1, 34-48.

81. Healy, R.W. Estimating Groundwater Recharge; Cambridge University Press: Cambridge, UK, 2010.

82. Santarosa, L.V.; Gastmans, D.; Sitolini, T.P.; Kirchheim, R.E.; Betancur, S.B.; de Oliveira, M.E.D.; Campos, J.C.V.; Manzione, R.L. Assessment of groundwater recharge along the Guarani aquifer system outcrop zone in São Paulo State (Brazil): An important tool towards integrated management. Environ. Earth Sci. 2021, 80, 95. [CrossRef]

83. Haim, G.; Ronen, D.; Magaritz, M. Anion Exclusion During Transport through the Unsaturated Zone. J. Hydrol. 1986, 87, 267-283

84. Delin, G.N.; Healy, R.W.; Landon, M.K.; Böhlke, J.K. Effects of topography and soil properties on recharge at two sites in an agricultural field1. JAWRA J. Am. Water Resour. Assoc. 2000, 36, 1401-1416. [CrossRef]

85. Manna, F.; Murray, S.; Abbey, D.; Martin, P.; Cherry, J.; Parker, B. Spatial and temporal variability of groundwater recharge in a sandstone aquifer in a semiarid region. Hydrol. Earth Syst. Sci. 2019, 23, 2187-2205. [CrossRef]

86. Delin, G.N.; Healy, R.W.; Lorenz, D.L.; Nimmo, J.R. Comparison of local- to regional-scale estimates of ground-water recharge in Minnesota, USA. J. Hydrol. 2007, 334, 231-249. [CrossRef]

87. Pragnaditya, M.; Mukherjee, A.; Bhanja, S.N. Groundwater Recharge under Varied Land Use Regions in the Semi-Arid Parts of Western West Bengal, India. In Proceedings of the AGU Fall Meeting Abstracts, San Francisco, CA, USA, 12-16 December 2016.

88. Hayati, H.N.; Yusoff, I.; Raksmey, M. Comparison of Applications to Evaluate Groundwater Recharge at Lower Kelantan River Basin, Malaysia. Geosciences 2020, 10, 289.

89. Ebrahimi, H.; Ghazavi, R.; Karimi, H. Estimation of Groundwater Recharge from the Rainfall and Irrigation in an Arid Environment Using Inverse Modeling Approach and RS. Water Resour. Manag. 2016, 30, 1939-1951. [CrossRef] 